\title{
The forces driving clonal expansion of the HIV-1 latent reservoir
}

\author{
Runxia Liu', Francesco R. Simonetti ${ }^{2}$ and Ya-Chi Ho ${ }^{1 *}$ (D)
}

\begin{abstract}
Despite antiretroviral therapy (ART) which halts HIV-1 replication and reduces plasma viral load to clinically undetectable levels, viral rebound inevitably occurs once ART is interrupted. HIV-1-infected cells can undergo clonal expansion, and these clonally expanded cells increase over time. Over 50\% of latent reservoirs are maintained through clonal expansion. The clonally expanding HIV-1-infected cells, both in the blood and in the lymphoid tissues, contribute to viral rebound. The major drivers of clonal expansion of HIV-1-infected cells include antigendriven proliferation, homeostatic proliferation and HIV-1 integration site-dependent proliferation. Here, we reviewed how viral, immunologic and genomic factors contribute to clonal expansion of HIV-1-infected cells, and how clonal expansion shapes the HIV-1 latent reservoir. Antigen-specific CD4 ${ }^{+} \mathrm{T}$ cells specific for different pathogens have different clonal expansion dynamics, depending on antigen exposure, cytokine profiles and exhaustion phenotypes. Homeostatic proliferation replenishes the HIV-1 latent reservoir without inducing viral expression and immune clearance. Integration site-dependent proliferation, a mechanism also deployed by other retroviruses, leads to slow but steady increase of HIV-1-infected cells harboring HIV-1 proviruses integrated in the same orientation at specific sites of certain cancer-related genes. Targeting clonally expanding HIV-1 latent reservoir without disrupting $\mathrm{CD}^{+} \mathrm{T}$ cell function is a top priority for HIV-1 eradication.
\end{abstract}

Keywords: HIV-1 latent reservoir, Clonal expansion, Antigen-driven proliferation, Homeostatic proliferation, HIV-1 integration site, Aberrant proliferation, HIV-1 cure, HIV-1 proviral landscape, Defective HIV-1 proviruses, Chromatin accessibility

\section{Background}

HIV-1 persists in the latent reservoir as a major barrier to cure [1-3]. $\mathrm{CD}^{+} \mathrm{T}$ cells harboring latent and transcriptionally inactive HIV-1 proviruses do not express viral antigens and do not die of viral cytopathic effects or immune clearance. While ART targets viral enzyme function or viral entry, ART does not affect HIV-1 transcription nor kills infected cells. Because of the extremely long half-life ( 43-44 months) $[4,5]$ of the latent reservoir, it takes $>73$ years for the latent reservoir to decay to zero [4]. Therefore, all HIV-1-infected individuals need to take life-long ART. There are 37 million people living with HIV-1 and only $62 \%$ of them requiring HIV-1 treatment have access to ART [6]. Given the adverse effects, economic burden and social stigma of

\footnotetext{
* Correspondence: ya-chi.ho@yale.edu

'Department of Microbial Pathogenesis, Yale University, New Haven, CT 06519, USA

Full list of author information is available at the end of the article
}

life-long ART for the HIV-1-infected individuals, therapeutic strategies targeting the HIV-1 latent reservoir is required to end the HIV-1 endemic.

\section{Main text}

The HIV-1 latent reservoir undergoes clonal expansion The landscape of the HIV-1-infected cells is shaped by viral cytopathic effects, immune clearance and clonal expansion of the infected cells (Fig. 1a). The size of the latent reservoir correlates with the area-under-the-curve of the product of viral load and CD4 count during acute infection, suggesting that reservoir seeding happens during peak viremia [7]. Indeed, early HIV-1-infection (within 4 weeks of expansion) can persist as clonally expanded HIV-1-infected cells [8]. However, it is the HIV1-infected cells which are archived immediately before ART (which are likely survivors of ongoing immune selection pressure), as opposed to the initial peak viremia clones, which persist and undergo clonal expansion after 


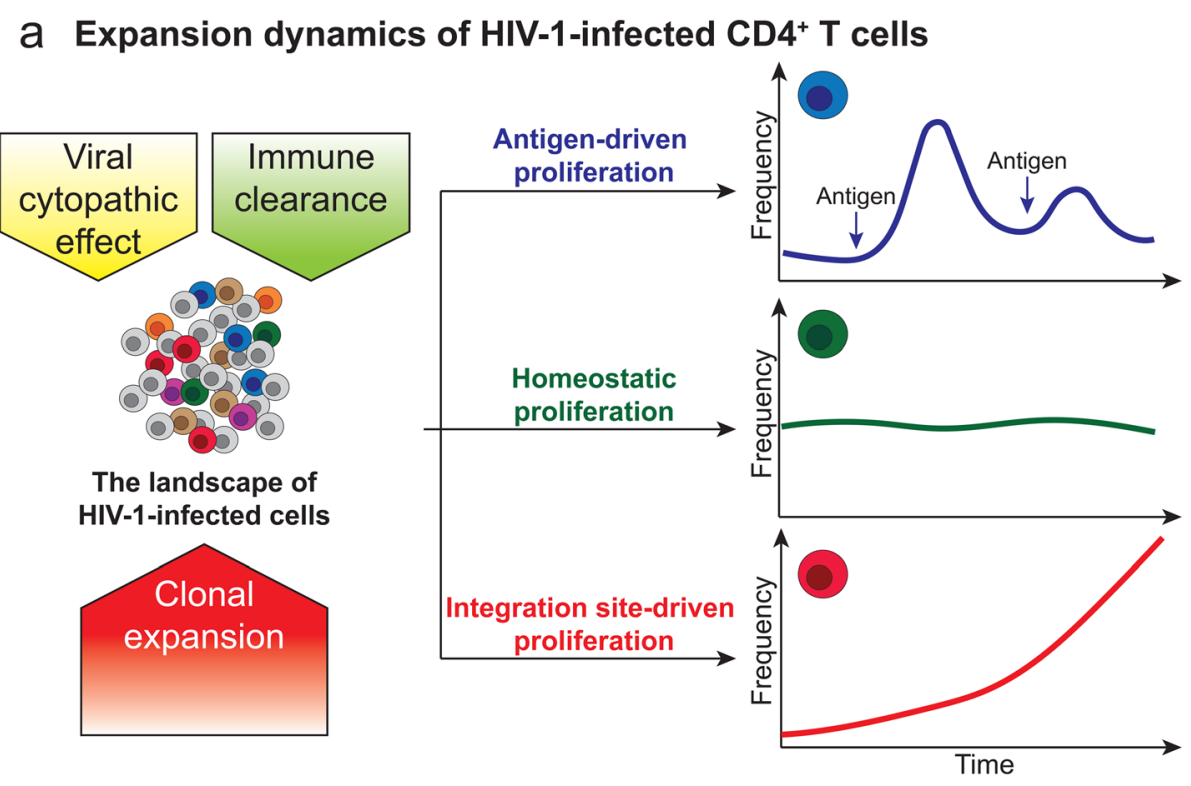

b Expansion dynamics of antigen-specific $\mathrm{CD4}^{+} \mathrm{T}$ cells

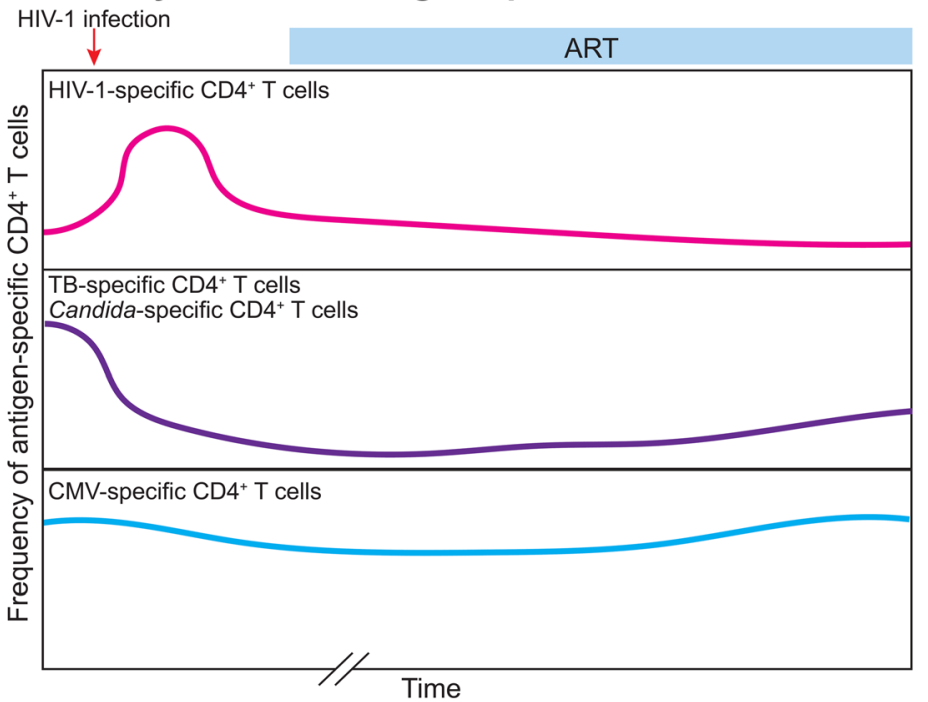

Fig. 1 Expansion dynamics of HIV-1-infected CD4 ${ }^{+}$T cells during HIV-1 infection. a The landscape of HIV-1-infected cells is shaped by viral cytopathic effect, immune clearance and clonal expansion of the HIV-1-infected cells. The major drives of clonal expansion of HIV-1-infected cells include antigen-driven proliferation, homeostatic proliferation, and integration site-driven proliferation. HIV-1-infected antigen-specific cells surge as antigen stimulation peaks and wane as the antigen-specific response subsides. Homeostatic proliferation driven by cytokines such as IL-7 and IL-15 does not induce viral antigen expression and evades immune clearance. These two mechanisms are controlled by physiologic immune responses. In contrast, HIV-1 integration may drive aberrant cellular proliferation, which is not affected by host immune feedback controls. Thus, HIV-1 integration site-driven clonal expansion leads to a slow but steady increase of HIV-1-infected cells. Y axis, frequency of HIV-1-infected cells. b The clonal expansion dynamics of antigen-specific $C D 4^{+} T$ cells depends on antigen exposure, cytokine profiles and exhaustion phenotypes. HIV-1-specific CD4 ${ }^{+}$T cells increase during acute HIV-1 infection and decline after ART initiation as the majority of HIV-1 antigen is eliminated. Despite chronic antigen exposure, these HIV-1-specific CD4 ${ }^{+} \mathrm{T}$ cells are few, dysfunctional and impaired in proliferation capacity. On the other hand, TB-specific and Candida-specific CD4 ${ }^{+} \mathrm{T}$ cells are preferentially infected and depleted during HIV-1-infection, which can be partially restored upon ART. In contrast, CMV-specific CD4 ${ }^{+} \mathrm{T}$ cells are relatively protected from HIV-1 infection and remain relatively abundant and functional during HIV-1 infection

years of ART $[9,10]$. The persistence of HIV-1-infected cells does not mean that the same HIV-1-infected cells remain unchanged over the course of ART. HIV-1infected cells undergo clonal expansion and the proportion of clonally expanded HIV-1-infected cells increase over time [11-13]. As $>90 \%$ of HIV-1 proviruses are defective [14-16], it was thought that these clonally expanded cells mainly harbor defective HIV-1 
proviruses. However, three independent studies demonstrated that $\sim 56 \%$ of cells harboring replicationcompetent HIV-1 proviruses undergo clonal expansion [17-19]. Similarly, HIV-1-infected cells in the lymphoid tissue undergo clonal expansion with no new rounds of ongoing replication under suppressive ART, as evidenced by the lack of phylogenetic evolution [10, 20, 21]. Considering that these observations are likely affected by under sampling (many clones are not large enough to be detected as expanded), these studies suggest that the majority of the latent reservoir are likely maintained by clonal expansion [17-19, 22]. Therefore, targeting the clonally expanding latently infected cells is a high-priority goal for HIV-1 eradication.

The major discrepancy in understanding HIV-1 clonal expansion dynamics is that the size of the HIV-1 latent reservoir does not change over time [4] but the cells that maintain this reservoir expand over time [17-19]. This indicates a major gap in understanding of clonal expansion dynamics during HIV-1-infection. We propose that 1) HIV-infected clones wax and wane in response to antigen stimulation, as part of the physiological immune responses of the host; 2) homeostatic proliferation induces expansion of HIV-1-infected cells without causing immune recognition and thus replenishes the latent reservoir; 3) HIV-1 integration site-dependent proliferation drives slow but steady increase of the infected cells (Fig. 1a).

\section{Clonally expanded HIV-1-infected $\mathrm{CD} 4^{+} \mathrm{T}$ cells in the peripheral blood and the lymphoid tissue contribute to viral rebound}

There is considerable debate about which cellular subsets and anatomical compartments are the actual HIV-1 latent reservoir, and which of the reservoirs causes viral rebound during treatment interruption. To examine the sources of rebound viremia in vivo, analytical treatment interruption (ATI) were used in ART-suppressed, HIV1-infected individuals [23]. By analyzing HIV-1 RNA sequences from limiting dilution viral outgrowth cultures and rebound plasma viruses after ATI, one study failed to find the identical matching HIV-1 sequences from the two sampling time points [24] while another study does [25]. Although the above study estimated the low contribution of HIV-1-infected cells in the peripheral blood as the major reservoir [26], multiple studies have shown that HIV-1-infected peripheral $\mathrm{CD}_{4}^{+} \mathrm{T}$ cells contribute to viral rebound [27-29]. First, activated HIV-1 proviruses by latency reversing agents from $\mathrm{CD}^{+}{ }^{+} \mathrm{T}$ cells share identical sequence with the plasma viremia during ATI, indicating HIV-1-infected $\mathrm{CD} 4^{+} \mathrm{T}$ cells contribute to viral rebound [27]. Second, identical HIV-1 proviruses and cell-associated RNA sequences from clonally expended HIV-1-infected cells in the peripheral blood and in the lymphoid tissue on ART match the plasma
RNA after ATI, suggesting in vivo clonally expanded $\mathrm{CD}^{+} \mathrm{T}$ cells in the peripheral blood and the lymphoid tissue are likely responsible for the viral rebound [28]. Third, a more comprehensive study showed various cell subsets and anatomical compartments including peripheral blood contribute to rebound viremia [29]. In individuals with larger clonally expanded HIV-1-infected cells in peripheral blood and lymphoid tissues, more identical sequences were found to match rebound plasma viruses, indicating the importance of clonal expansion in HIV-1 persistence and rebound dynamics [29].

\section{Expansion dynamics differ in HIV-1-infected $\mathrm{CD} 4^{+} \mathrm{T}$ cells harboring different subsets of proviruses}

Despite ART, chronic immune activation persists in HIV-1-infected individuals [30, 31]. While ART blocks new rounds of infection to the neighboring cells, ART does not inhibit HIV-1 expression in the existing infected cells. Therefore, even under suppressive ART, the HIV-1 LTR promoter remains active, driving cellassociated HIV-1 RNA expression [32], production of viral particles and consequent $\mathrm{T}$ cell activation [33]. As both intact and defective HIV-1 proviruses may have intact HIV-1 promoter function [14], both intact and defective HIV-1 proviruses have the potential to express viral antigens upon stochastic reactivation [14, 34]. Further, as the frequency of defective proviruses $(100-1000$ per million $\mathrm{CD} 4^{+} \mathrm{T}$ cells) outnumbers the frequency of intact HIV-1 proviruses $\left(1-100\right.$ per million $\mathrm{CD}^{+} \mathrm{T}$ cells) [14-16, 35], defective proviruses that can produce viral antigens will be an important source for chronic immune activation. The majority (>90\%) of HIV-1infected proviruses are defective due to packaging signal deletions, large internal deletions, APOBEC3G-induced hypermutations and point mutations [14, 16, 34]. Using limiting dilution cell-associated RNA sequencing, it was shown that defective proviruses, such as those containing APOBEC3G-mediated hypermutations, are readily producing HIV-1 RNA without ex vivo stimulation [32]. In vitro analysis revealed that HIV-1 proviruses having packaging signal deletions can produce readily detectable levels of HIV-1 p24 antigen [14, 34]. Functional analysis revealed that these HIV-1 proviruses, despite having packaging signal deletions or inactivating APOBEC3Gmediated G-to-A hypermutations, can induce $\mathrm{CD} 8^{+} \mathrm{T}$ cell recognition [34]. Of note, large internal deletions seem to have dominant negative effect on viral protein production - that in proviruses with both hypermutations and large internal deletions, the HIV-1 proviruses will not be able to produce viral proteins and will not induce $\mathrm{CD}^{+} \mathrm{T}$ cell recognition of the infected cells [34]. While some proviruses with large internal deletions can activate alternative splice sites to produce spliced RNA products and potentially aberrant viral proteins [34, 36], 
the large internal deletions frequently encompass splice sites and splice elements and disables viral protein production [34, 37]. Therefore, $\mathrm{CD}^{+} \mathrm{T}$ cells harboring proviruses with large internal deletions are released from negative selective forces, and maybe preferentially expanded over time $[16,34]$. These lines of evidence suggest that despite effective ART, HIV-1-infected cells, including those containing intact and defective proviruses, can continue to cause immune activation.

\section{Antigen stimulation drives dynamic expansion and contraction of HIV-1-infected cells}

Clonal expansion of HIV-1-infected cells is driven by antigen-driven proliferation [38, 39], homeostatic proliferation $[40,41]$ and integration site-driven proliferation [11-13] (Fig. 1a). As HIV-1 proviruses reside in memory $\mathrm{CD}^{+}{ }^{+} \mathrm{T}$ cells, it has been thought that the expansion dynamics of HIV-1-infected cells follows the physiologic expansion of memory $\mathrm{CD}_{4}^{+} \mathrm{T}$ cells by antigen-driven stimulation or cytokine-driven homeostatic proliferation (through interleukin (IL)-7 and IL-15). Indeed, in an HIV-1-infected individual who had uncontrolled metastatic squamous cell carcinoma, an HIV-1-infected CD $4^{+}$ $\mathrm{T}$ cell clone expanded as the tumor progressed and contracted when cancer treatment was initiated [38]. Despite adherence to ART and the absence of drugresistant viruses, plasma viral load surged as the tumor relapsed, suggesting that the expansion of the HIV-1infected clone and HIV-1 expression were induced by a tumor-specific immune response. Elegant examination of this example of antigen-driven proliferation of HIV-1infected cells provides insights into some previously unexplained clinical scenarios, such as the presence of viral blips and predominant plasma clones despite ART. First, in HIV-1-infected individuals adherent to ART, clinically detectable levels of plasma viremia can still be occasionally captured. Such intermittent low-level viremia (plasma viral load $<200$ copies $/ \mathrm{ml}$ ), termed viral blips, is devoid of drug resistance mutations, does not benefit from treatment intensification, and does not require changes in antiretroviral regimens [42]. Phylogenetic analysis during episodes of low-level viremia revealed genetically identical viruses termed the predominant plasma clones [43-45]. Based on the antigen-driven HIV-1infected $\mathrm{T}$ cell clonal expansion dynamics, it is likely that antigen stimulation activates HIV-1-infected, antigenspecific $\mathrm{CD}^{+} \mathrm{T}$ cells and drives HIV-1 expression and clonal expansion. Thus, the predominant plasma clones which wax (during antigen stimulation) and wanes (when antigen stimulation resolves) over time [46]. While concurrent ART remains effective in preventing ongoing HIV-1 replication, ART does not inhibit HIV-1 LTR promoter function, viral RNA expression or clonal expansion of the HIV-1-infected cells. Such antigen-driven proliferation of
HIV-1-infected cells is likely not integration site dependent - that HIV-1 integration sites in these proliferated cells, likely driven by antigen stimulation, are typically not in specific cancer-related genes (see below) [38, 47]. These HIV-1-infected, antigen-specific $\mathrm{CD}^{+}{ }^{+} \mathrm{T}$ cells undergo HIV-1 expression and clonal expansion, leading to transient residual viremia and viral blips [47]. Thus, antigen stimulation-induced viral blips are typically transient, which surges as antigen stimulation peaks and wanes as the antigen-specific response subsides. However, in depth characterization of nine individuals with residual viremia caused by expanded clones carrying replication-competent proviruses, showed long periods of stable or intermittent viral production (median 3.2 years) [47], suggesting that in some cases the response to certain antigenic stimulations may persist over time.

\section{Expansion dynamics differ in HIV-1-infected $\mathrm{CD}^{+}{ }^{+} \mathrm{T}$ cells specific for different pathogens}

The expansion dynamics of HIV-1-infected cells differ between $\mathrm{CD}_{4}^{+} \mathrm{T}$ cells specific for different antigens (Fig. 1b). HIV-1-specific $\mathrm{CD}^{+}{ }^{+} \mathrm{T}$ cells are required for HIV-1 control [48]. Presumably both HIV-1infected $\mathrm{CD}^{+} \mathrm{T}$ cells and professional antigen presenting cells can provide constant immune activation to HIV-1-specific $\mathrm{CD}_{4}^{+} \mathrm{T}$ cells and induce HIV-1specific $\mathrm{CD}^{+}{ }^{+} \mathrm{T}$ cell proliferation. The HIV-1-infected cells are enriched in memory cells polarized in Th1 [49] or expressing effector memory phenotypes [50]. While HIV-1-specific $\mathrm{CD} 4^{+} \mathrm{T}$ cells are readily detected in treated and untreated HIV-1-infected individuals [51], these HIV-1-specific $\mathrm{T}$ cells are few, dysfunctional and impaired in proliferation capacity $[52,53]$, due to $\mathrm{T}$ cell activation [54], chronic immune activation [55], upregulation of inhibitory molecules [56-58], and the loss of lymphoid structure supporting CD4 homeostasis [59-61] (Fig. 1a). While HIV-1 preferentially infects HIV-1-specific cells in the context of acute and recrudescent HIV-1 infection [39], cytopathic effects [62] may lead to clonal depletion of HIV-1-infected cells. Early ART, which halts ongoing immune activation and new rounds of viral infection, restores the frequency and proliferative responses of HIV-1-specific CD $4^{+} \mathrm{T}$ cells compared to untreated individuals [63]. Therefore, due to the complexity of ongoing antigen stimulation (which drives proliferation) and immune exhaustion (which reduces proliferation capacity), it remains to be determined how HIV-1-specific $\mathrm{CD}^{+}{ }^{+} \mathrm{T}$ cells, and the HIV-1 proviruses which reside in them, expand or contract over the course of HIV-1 infection, before and after ART introduction.

The difference in susceptibility of clonal depletion is potentially due to the cytokine profiles of the pathogen 
specific CD4 ${ }^{+} \mathrm{T}$ cells (Fig. 1b). Similar to HIV-1-specific $\mathrm{CD}^{+}{ }^{+} \mathrm{T}$ cells, Mycobacterium tuberculosis (TB)-specific $\mathrm{CD}^{+}{ }^{+} \mathrm{T}$ cells are preferentially depleted early during HIV-1 infection due to viral cytopathic effect and the loss of proliferation capacity due to chronic immune activation [64]. TB-specific $\mathrm{CD}^{+} \mathrm{T}$ cells have increased expression of CCR5 and produce IL-2 and IL-2 receptor CD25 [64, 65]. Binding of IL-2 to CD25 promote cellular proliferation and HIV-1 replication. Thus, TB-specific $\mathrm{CD}_{4}^{+} \mathrm{T}$ cells are preferentially infected and depleted by HIV-1 infection. After ART, TB-specific CD4 ${ }^{+} \mathrm{T}$ cells can be restored [66]. Similarly, Candida albicans-specific $\mathrm{CD}^{+}{ }^{+} \mathrm{T}$ cells are also preferentially infected by HIV-1 and depleted during progressive HIV-1 infection [67]. Candida specific-CD $4^{+} \mathrm{T}$ cells express more IL-2, IL-17 and CD25 and are highly susceptible to HIV-1 infection. Candida specific-CD4 ${ }^{+} \mathrm{T}$ cells are preferentially lost at early HIV-1 infection with ongoing CD4 depletion [67]. In contrast, cytomegalovirus (CMV) specific $\mathrm{CD}^{+}{ }^{+} \mathrm{T}$ cells are preserved in function, quantity and proliferation capacity during HIV-1 infection [68-70]. CMV-specific $\mathrm{CD}^{+}{ }^{+} \mathrm{T}$ cells express lower level of PD-1 than HIV-1specific $\mathrm{CD}^{+} \mathrm{T}$ cells $[57,71]$. The cytokine profile of $\mathrm{CMV}$-specific $\mathrm{CD} 4^{+} \mathrm{T}$ cells provide survival benefit during HIV-1-infection. For example, CMV-specific CD $4^{+} \mathrm{T}$ cells express high levels of MIP- $1 \beta$ while TB-specific $\mathrm{CD}^{+} \mathrm{T}$ cells do not [65]. MIP- $1 \beta$ binds to and downregulates its ligand CCR5, preventing HIV-1 infection [72]. Further, CMV-specific $\mathrm{CD} 4^{+} \mathrm{T}$ cells produce CD57, a marker for limiting proliferation, which restricts HIV-1 replication [73, 74]. Thus, CMV-specific $\mathrm{CD} 4^{+} \mathrm{T}$ cells are less susceptible to HIV-1 infection and are preserved. During latent $\mathrm{CMV}$ infection, consistent low level of antigen stimulation maintains memory inflation of short-lived, functional CMV-specific T cells [75]. Thus, $\mathrm{CMV}$-specific $\mathrm{CD}_{4}^{+} \mathrm{T}$ cells remains relatively functional during HIV-1 infection. CMV-specific CD4+ T cells, if infected with HIV-1 (although less susceptible), may proliferate at a higher rate due to intermittent CMV antigen stimulation and the retained proliferation capacity.

\section{HIV-1-infected cells evade immune clearance through IL- 7-driven homeostatic proliferation}

Homeostatic proliferation maintains the repertoire of memory $\mathrm{CD}^{+}{ }^{+} \mathrm{T}$ cells [76-78]. During chronic HIV-1infection, the proliferation capacity of $\mathrm{CD}^{+} \mathrm{T}$ cells is significantly impaired because of decreased IL-7 receptor expression [79], chronic immune activation [80], immune exhaustion $[58,81,82]$, and the destruction of lymphoid tissue [83]. IL-7 expression level is upregulated in response to $\mathrm{CD}^{+} \mathrm{T}$ cell depletion during HIV-1infection [84], promoting proliferation of HIV-1-infected $\mathrm{CD}_{4}^{+} \mathrm{T}$ cells. Interestingly, IL-7 induces proliferation of
HIV-1-infected cells without reactivating latent HIV-1 $[85,86]$, suggesting that HIV-1-infected $\mathrm{CD}^{+} \mathrm{T}$ cells may undergo homeostatic proliferation without being recognized by immune surveillance.

\section{Retroviral integration into cancer-related genes promotes clonal expansion}

While HIV-1 does not cause cancer in the infected cell, many retroviruses induce insertional oncogenesis and uncontrolled clonal expansion of the infected cell. For example, the discovery of oncogene originates from research on retroviral pathogenesis. Rous sarcoma virus is the first retrovirus that was discovered and known to cause cancer in its avian host, leading to the discovery of oncogenes [87]. Lessons about retroviral-induced insertional oncogenesis in humans were learned from therapeutic retroviral vectors and human $\mathrm{T}$ lymphotropic virus (HTLV) infections.

Retroviral vectors have been used as a gene therapy tool to correct genetic diseases. For example, individuals with X-linked severe combined immunodeficiency (SCID-X1) were treated by gene therapy to restore interleukin receptor $\gamma$ gene in bone marrow $\mathrm{CD} 34^{+}$precursor cells using gammaretroviral vectors [88]. However, four out of the nine patients who received gene therapy developed $\mathrm{T}$ cell leukemia, due to the gammaretroviral vectors insertion-mediated activation of proto-oncogenes, such as BMI1 and CCND2 or disruption of tumor suppressor genes such as $C D K N 2 A$, resulting into uncontrolled $\mathrm{T}$ cells growth [89]. Such Moloney murine leukemia virus (MLV)-based gene therapy induces leukemia in treated patients, likely due to MLV preferentially integrating into the transcription start sites [90].

Understanding retroviral insertional oncogenesis led to the use of safer, non-oncogenic retroviral vectors such as lentiviruses. In an example of lentiviral vector mediated gene therapy for $\beta$-thalassemia, the lentiviral vector encoding $\beta$-globin integrated in the same orientation of the transcription regulator $H M G A 2$ gene, disrupted HMGA2-mediated transcriptional regulation, and caused clonal expansion of this T cell clone [91]. In another example, lentiviral vectors carrying the chimeric antigen receptor (CAR) cassette in the treatment of chronic lymphocytic leukemia integrated into the intron of the tumor suppressor gene TET2, disrupted TET2 regulatory region and led to a dominant clone $(94 \%$ at the peak of response) in vivo [92]. This suggests that nononcogenic lentiviruses can induce clonal expansion of the transduced primary $\mathrm{T}$ cells in vivo.

HTLV, the first reported human oncogenic retrovirus causes adult $\mathrm{T}$ cell lymphoma-leukemia (ATL) [93, 94]. While HTLV causes cancer through several mechanisms regardless of the integration site, such as viral $H B Z$ mRNA transcription and protein Tax, HTLV interaction 
with the host chromatin at the integration site is a major mechanism for oncogenesis (reviewed in [95]). Unlike HIV-1, HTLV has CTCF binding sites within the proviral genome, which allows distant host gene interactions through CTCF-mediated chromatin looping [96]. While initial integration does not favor specific chromosomes, HTLV integration into acrocentric chromosomes provides a higher survival benefit [97]. Similar to HIV-1, HTLV integration preferentially occurs at actively transcribed genes [98]. The host genomic environment at HTLV integration site determines HTLV clonal expansion in vivo and favors insertions with the same orientation as the nearest host gene [98]. Thus, over the scale of 50-60 years, a dominant clone grows out of host control and leads to ATL. Given the similarity between HIV-1 and HTLV induced clonal expansion in the infected lymphocytes, further examination of mechanisms of HIV-1-induced clonal expansion may provide therapeutic targets to disrupt HIV-1-driven clonal expansion without damaging the uninfected cells.

\section{Integration site-dependent proliferation drives the proliferation of HIV-1-infected cells}

HIV-1 preferentially integrates into introns of actively transcribed genes, both in vitro and in vivo [14, 99-101]. In these studies, HIV-1 integration sites were identified but at a small scale [100]. Using modified deep sequencing approaches to examine and HTLV integration sites developed by the Bangham group [98], thousands of HIV-1 integration sites in HIV-1-infected individuals were identified for a more comprehensive examination of the HIV-1 integration landscape [11]. Despite that HIV-lintegration into T cell genomes is biased by multiple viral and host factors (CPSF6 [102] and LEDGF/p75 [103]), cells harboring HIV-1 proviruses which are integrated into the exact same nucleotide is unlikely to come from two distinct integration events. Rather, it is more likely the result of one infection event followed by proliferation of the infected cells. Therefore, HIV-1 proviruses having the exact same integration site indicates clonal expansion of the infected cells. Using sonication-based random DNA shearing, the same HIV-1 integration site with different DNA shearing breakpoints indicates the number of cells that belong to the same clone. This method, called sonic abundance [104], identifies both the integration site and the number of clonally expanded HIV-1-infected cells. These integration site analyses revealed dramatic difference of HIV-1-integration landscape in vitro versus in vivo. First, the frequency of HIV-1 integration into cancer-related genes (12.5\%) in HIV-1-infected individuals is significantly higher than the frequency of cancer-related genes in the human genome (5.19\%) [12]. Second, the integration patterns in vivo and in vitro are strikingly different. During in vitro infection, HIV-1integration sites are relatively random throughout the introns of genes, both in the same and opposite orientation in respect to the host transcription unit [11, 12]. However, during in vivo infection in $\mathrm{CD} 4^{+} \mathrm{T}$ cells from virally suppressed HIV-1-infected individuals, HIV-1 integration sites are enriched in a small region in certain cancer-related genes, such as in the introns immediately upstream the translation start site of cancer-related genes $B A C H 2, M K L 2$ and STAT5B $[11,12]$. In addition, HIV-1 proviruses are integrated exclusively in the same orientation with the host transcription unit at these sites, which is the opposite of what happens in vitro (that HIV-1 integration into the same and opposite orientation is roughly equal [101]). HIV-1 integration into specific sites associated with clonal expansion in vivo, such as $B A C H 2, M K L 2, N F A T C 3$ and $S T A T 5 B$, have been captured in multiple studies, using different methods in different HIV-1-infected individuals $[11,12,105,106]$. These specific sites recur across individuals not because of preferential integration, as HIV-1 integration into these sites are not enriched during in vitro infections [11]. Similar to HIV-1 integration sites, simian immunodeficiency virus (SIV) with integration into $B A C H 2, M K L 2$ and STAT5B are found in SIV-infected macaques before ART [107]. Despite that the genomewide distribution of HIV-1 and SIV integration showed a high degree of overlap in vitro, it seems that more integrants are oriented in the convergent orientation of these genes in SIV-infected macaques under suppression, which is opposite from what observed from ART treated HIV-1infected individuals in vivo $[11,12,107]$. However, more SIV integration site data from long-term treated macaques are needed to determine whether there is positive selection of SIV proviruses integrated in genes associated with clonal expansion in individuals on ART. Nevertheless, the specific mechanisms driving HIV-1 integration sitedependent proliferation, which happens in vivo but not in vitro, remain unclear.

In some instances, these drives (antigen-driven proliferation, homeostasis-driven proliferation and integration site-driven proliferation) of clonal expansion may act together. HIV-1-infected CMV-specific $\mathrm{CD}^{+}{ }^{+} \mathrm{T}$ cells may inflate due to consistent CMV antigen stimulation at late stage of CMV infection [75]. CD127 (IL-7 receptor) are highly expressed on inflationary $\mathrm{CMV}$-specific $\mathrm{CD} 8^{+} \mathrm{T}$ cells [108] and may presumably be expressed on CMVspecific $\mathrm{CD}^{+} \mathrm{T}$ cells. If HIV-1 provirus happens to integrate into cancer-related genes, such as $B A C H 2$ and $M K L 2$, the infected cells may undergo aberrant proliferation $[11,12]$. All these factors could promote the proliferation of HIV-1-infected cells.

\section{HIV-1 proviruses which are integrated into specific cancer-related genes can be intact}

Whether clonally expanded HIV-1 proviruses in these specific sites of cancer-related genes are intact or 


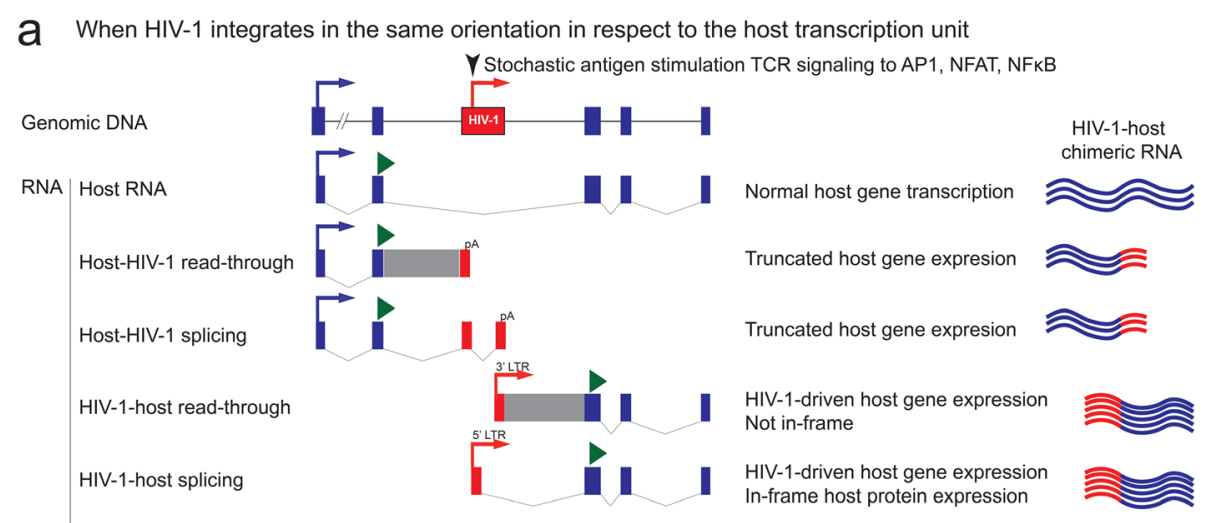

b When HIV-1 integrates in the opposite orientation in respect to the host transcription unit

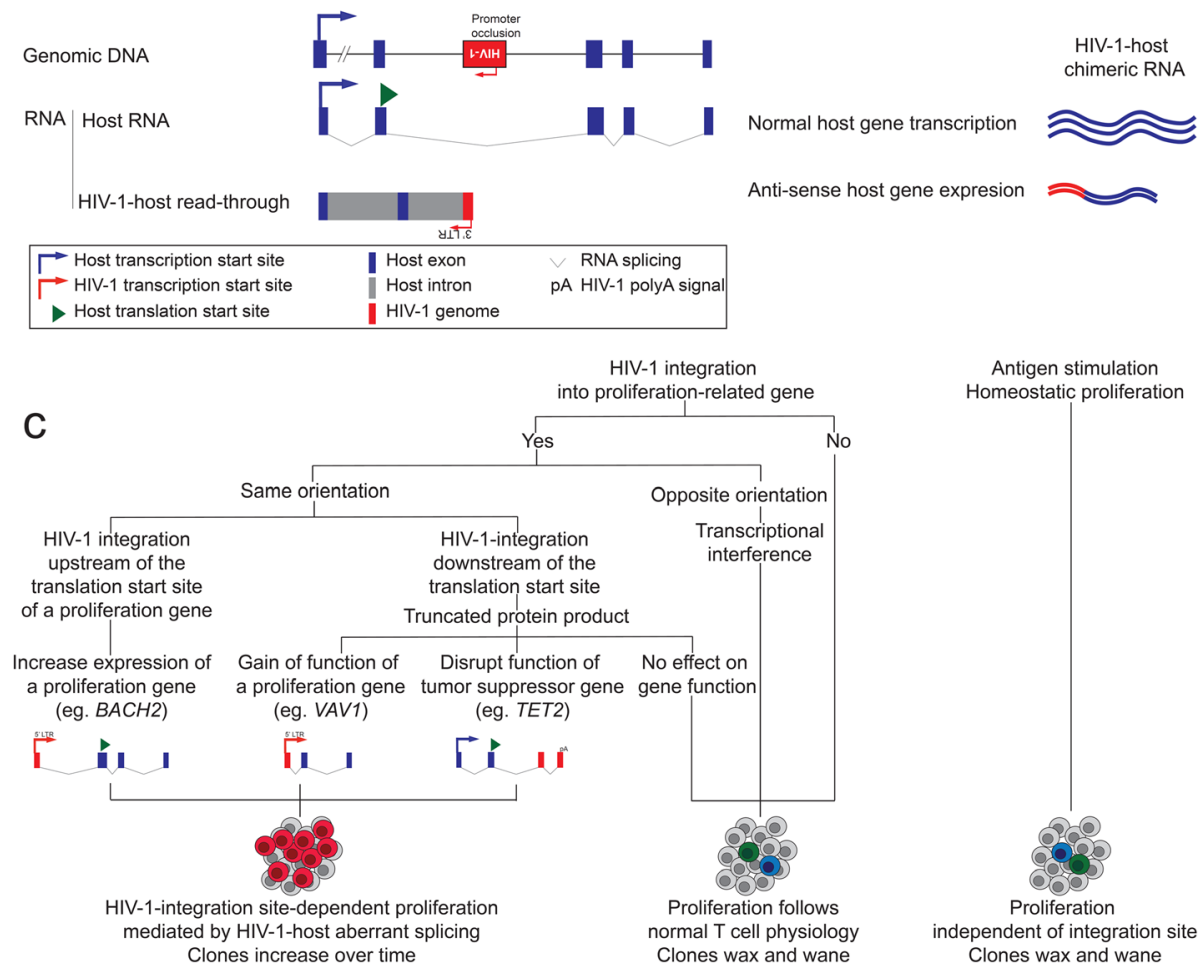

Fig. 2 Mechanisms of integration site-dependent clonal expansion of HIV-1-infected cells. HIV-1-host interactions at the integration site when HIV-1 is integrated in the same (a) or opposite (b) orientation in respect to the transcription unit. c HIV-1-driven integration site-dependent proliferation depends on the orientation, orientation and the functional consequences of the host gene in which HIV-1 is integrated in

defective was unknown. Since over $90 \%$ of HIV-1 are defective [14-16], based on the possibility, the majority of clonally expanded cells should harbor defective HIV-1 proviruses [13]. However, it remains technically challenging to examine HIV-1 integration site and HIV-1 genome integrity at the same time in a high throughput way to examine the integration site landscape of replication competent HIV-1. First, when using random shearing for HIV-1 integration site analysis, the HIV-1 genome is disrupted, preventing simultaneous examination of HIV1 integration site and HIV-1 genome integrity at the same time [11-13]. Second, in viral outgrowth experiments trying to capture the clonality of replication competent HIV-1, cells in the viral outgrowth cultures underwent multiple rounds of in vitro infection, and HIV-1 integration sites captured in the culture wells cannot reflect HIV-1 integration sites in vivo [17-19]. Third, full-length HIV-1 proviral sequencing methods, which can capture clonally expanded HIV-1, amplifies regions spanning HIV-1 genome and excludes integration site information $[14,16]$.

In response to this challenge, several methods were developed to examine HIV-1 integration site and HIV-1 genome integrity at the same time. First, using whole 
genome amplification by phi29 polymerase, the Lichterfeld group [109] and the Kearney group [110] developed matched integration site and proviral sequencing to examine the integration site and HIV-1 near-full length genome sequencing at the same time. Second, using limiting dilution culture and CD3/CD28-mediated proliferation, the Siliciano group sequenced the HIV-1 integration site and HIV-1 near full-length genome from $\mathrm{CD}^{+} \mathrm{T}$ cells undergoing ex vivo proliferation. Of note, cells harboring replication competent HIV-1 died of viral cytopathic effects in this study after 3 weeks of maximum $\mathrm{T}$ cell activation, and only defective proviral clones were identified. The HIV-1 proviruses integrated into the cancer-related gene $B A C H 2$ ( 2 clones total) from these two methods are defective. However, since both methods attempts to examine all HIV-1 proviruses, the majority of the integration sites captured are from defective proviruses, and the number of integration sites of intact HIV-1 remain limited to draw conclusions. The fact that over $50 \%$ cells harboring infectious HIV-1 proviruses are from clonal expansion [17-19] suggests that other methods which can preferentially enrich for intact HIV-1 are needed to examine the HIV-1 integration site landscape of replication competent proviruses. Our group developed HIV-1 Sortseq which identifies HIV-1infected cells expressing readily detectable levels of HIV1 RNA [111]. Using HIV-1-chimeric RNA junction analysis, we identified cells which harbor inducible HIV1 integrated into cancer-related genes found in clonally expanded cells in vivo, such as BACH2 and NFATC3. Thus, both intact and defective HIV-1can be integrated into cancer-related genes, and both intact and defective HIV-1 proviruses can undergo clonal expansion. As the landscape of HIV-1 integration is heterogeneous, thus it is difficult to draw conclusions. Finding defective proviruses integrated into recurrent integration genes such as $B A C H 2$ does not indicate that all HIV-1 integrated into $B A C H 2$ are defective. Similarly, finding clonally expanded cells integrated into non-cancer related genes does not indicate that HIV-1 integration into cancerrelated genes does not cause clonal expansion. A more high-throughput method which can break the technical barrier (that $90 \%$ of the sequences or proviruses isolated are defective) and detect HIV-1 integration sites of intact HIV-1 proviruses is necessary to understand HIV-1 integration site-dependent clonal expansion mechanisms.

\section{Mechanisms of integration site-dependent proliferation}

The majority of HIV-1 proviruses are integrated into the introns of actively transcribed genes [100]. HIV-1 can be integrated into the host transcription unit in the same (Fig. 2a) or opposite (Fig. 2b) orientation. When HIV-1 is integrated in the same orientation, the host and the HIV-1 promoter compete for the RNA polymerase and the transcription machinery, creating transcriptional interference. Transcriptional interference is typically thought as a mechanism that the host gene expression suppresses HIV-1 gene expression through viral promoter occlusion [112, 113] (Fig. 2a and b). For HIV-1 proviruses integrated in the same orientation as the host transcription unit (Fig. 2a), transcription from host gene leads to readthrough transcription into HIV-1 provirus or transcriptional termination at the HIV-1 polyA signal [113]. For HIV-1 proviruses integrated in the opposite orientation as the host transcription unit (Fig. 2b), viral promoter occlusion reduces the level of HIV-1 transcription [112].

Upon $\mathrm{T}$ cell activation, such as antigen stimulation which signals through $\mathrm{T}$ cell receptor pathways, transcription factors AP1, NFAT and NFkB translocate into the nucleus, bind to the respective binding sites on HIV-1 promoter and lead to stochastic HIV-1 activation. Such T cell activation relieves the aforementioned host-mediated transcriptional interference and allows HIV-1-driven transcription [113]. Therefore, upon stimulation, for HIV-1 proviruses integrated in the same orientation as the host transcription unit, HIV-1 promoter drives HIV-1 transcription and host gene expression through HIV-1-to-host RNA splicing (Fig. 2a, see below) [106, 111]. For HIV-1 proviruses integrated in the opposite orientation as the host transcription unit, HIV-1 3' LTR can drive anti-sense host RNA transcription and can potentially interfere with normal host gene transcription [111] (Fig. 2b).

When HIV-1 dominates over the host promoter upon stochastic activation, HIV-1 promoter drives aberrant host gene transcription. This means that the host gene expression is controlled by HIV-1 promoter activity not under cellular regulation. Detailed analysis on HIV-1host RNA splicing revealed the importance of HIV-1driven aberrant host gene expression at the integration site as a mechanism for integration site-dependent proliferation. Upon stochastic activation, HIV-1 promoter drives HIV-1 transcription and viral RNA production. Typically, HIV-1 RNA splices from HIV-1 splice donors (such as the major splice donor) to HIV-1 splice acceptors and produces spliced HIV-1 RNA. However, HIV-1 RNA can also splice from a HIV-1 splice donor into a host splice acceptor $[106,111,113,114]$ (Fig. 2a). Therefore, when HIV-1 is integrated upstream of the host gene translation start site, such as $B A C H 2, M K L 2$ and STAT5B [11, 12, 106], HIV-1 promoter drives HIV-1 transcription and induces RNA splicing from HIV-1 major splice donor into the host gene splice acceptor, and leads to transcription of the full coding sequence of the host gene, such as in the proliferation-related gene $B A C H 2[106,111]$. When HIV-1 is integrated into a proliferation-related gene downstream of the translation start site, such as the proto-oncogene VAV1, HIV-1 
interrupts into the middle of the VAV1 coding sequencing, leading to $\mathrm{N}$-terminal truncated VAV1 protein expression. As $\mathrm{N}$-terminal VAV1 truncation removes the regulatory region of VAV1, this HIV-1-driven truncated VAV1 expression leads to increased cellular proliferation [111] (Fig. 2c). A similar example in lenviral transduction for chimeric antigen receptor (CAR)-T cell editing, a lentiviral insertion into a tumor suppressor gene TET2 downstream of the host gene translation start site leads to host-to-lentiviral splicing into the lentiviral genome and transcriptional termination, leading to $\mathrm{C}$-terminal truncation of the tumor suppressor gene TET2 expression and increased proliferation of the $\mathrm{T}$ cell clone [92] (Fig. 2c).

HIV-1 integration into cancer-related gene alone does not determine integration site-dependent proliferation (Fig. 2c). First, it depends on the location and direction of the integration event [11, 12]. Second, it depends on whether the resulting HIV-1-induced aberrant host gene transcription induces a significant change in the gene expression and function, such as increased proliferationrelated gene expression (such as $B A C H 2$ ), gain-offunction truncation in a proliferation-related gene (such as $V A V 1)$, or loss-of-function truncation in a tumor suppressor gene (TET2). Of note, in overt $\mathrm{T}$ cell activation, such as antigen-driven proliferation and homeostatic proliferation, the proliferation of the infected cell does not depend on the HIV-1 integration site. Clonally expanded cells can still be captured in antigen-induced proliferation harboring HIV-1 integrated into sites irrelevant to proliferation [38]. The difference is that while antigen stimulation follows host immune homeostasis control and the HIV-1-infected clones may wane upon antigen removal, HIV-1-driven integration site-dependent proliferation will gradually increase over time (Fig. 2c), although such increase may take a scale of years of in vivo selection to be observed $[11,12]$.

\section{HIV-1 integration site-dependent clonal expansion - does} the chromatin environment matter?

The integration sites that are found repeatedly, in vivo but not in vitro, are associated with integration sitedriven proliferation $[11,12,105]$. These genes are termed "recurrent integration genes" [115]. While HTLV mediates chromatin looping through CTCF sites within the HTLV genome and changes the enhancer landscape, HIV-1 proviruses do not have CTCF sites to similarly alter chromatin structure [96]. Still, researchers hypothesize that local chromatin environment contributes to clonal expansion only when HIV-1 proviruses are integrated in these recurrent integration sites. For example, in an in vitro model, it was proposed that these recurrent integration genes are located near the nuclear pore where HIV-1 integration occurs $[115,116]$. These recurrent integration genes are spatially clustered during $\mathrm{T}$ cell activation and proximal to super-enhancers [115]. By mapping the HIV-1 integration sites at the recurrent integration genes with a separate dataset of $\mathrm{CD}^{+} \mathrm{T}$ cell chromatin accessibility landscape using Assay for Transposase-Accessible Chromatin using sequencing (ATACseq), it seems like these recurrent integration genes have more accessible chromatin region near these HIV-1 integration sites, and therefore potentially contributes to clonal expansion. However, testing this hypothesis in $\mathrm{CD}_{4}^{+} \mathrm{T}$ cells from HIV-1-infected individuals remain challenging due to the rarity of HIV-1-infected cells and the lack of selection markers to identify these cells. In contrast, overlaying HIV-1 integration sites and ATACseq (from a separate aliquots of $\mathrm{CD} 4^{+} \mathrm{T}$ cells from the same individual) from three HIV-1-infected individuals suggests that HIV-1 proviruses may integrate into loci away from accessible regions [109]. Nevertheless, examination of chromatin accessibility at the HIV-1 integration site remains technically not possible, and whether the chromatin environment at the HIV-1 integration sites favors clonal expansion or prevents gene expression remains under debate.

\section{Conclusions}

While antigen-driven proliferation and homeostatic proliferation are under host immune regulation, HIV-1 integration site-driven proliferation is not inhibited by host immune feedback controls. Therefore, clones driven to expand by the effect of HIV-1 integration may accumulate over time, similar to how HTLV causes leukemia. While it takes 50-60 years for HTLV to induce cancer transformation of the infected cell, HIV-1 does not eventually cause cancer in the infected cell. Still, proliferation of HIV-1-infected cells through HIV-1-driven proliferation is a major mechanism of HIV-1 persistence. Targeting the proliferating HIV-1-infected cells without disrupting normal $\mathrm{CD}^{+} \mathrm{T}$ cell function is a top priority to eliminate the clonally expanding HIV-1 reservoir. For example, ongoing clinical trials are investigating whether inhibition of $\mathrm{T}$ cell proliferation can accelerate the decay of the latent reservoir (NCT03262441) [117]. Since homeostatic proliferation does not induce HIV-1 antigen expression, immune therapies requiring HIV-1 protein expression, such as broadly neutralizing antibodies, may not affect this expanding reservoir unless combined with strong reversal of HIV-1latency. Strategies targeting proliferation of HIV-1-infected cells, but not uninfected cells, should be searched to eliminate the clonally expanding latent reservoir.

\section{Abbreviations}

ART: Antiretroviral therapy; ATACseq: Assay for Transposase-Accessible Chromatin using sequencing; ATI: Analytical treatment interruption; ATL: Adult T cell lymphoma-leukemia; CAR: Chimeric antigen receptor; 
CMV: Cytomegalovirus; HIV-1: Human immunodeficiency virus type 1; HTLV: Human T lymphotropic virus; IL: Interleukin; MLV: Moloney murine leukemia virus; SCID-X1: X-linked severe combined immunodeficiency; SIV: Simian immunodeficiency virus; TB: Mycobacterium tuberculosis

\section{Acknowledgements}

Not applicable.

\section{Authors' contributions}

$\mathrm{RL}, \mathrm{FRS}$ and $\mathrm{Y}-\mathrm{CH}$ conceptualized and wrote the manuscript. All authors read and approved the final manuscript.

\section{Funding}

This work is supported by Yale Top Scholar, Rudolf J. Anderson Fellowship, NIH R01 Al141009, R61 DA047037, R21Al118402, W. W. Smith AIDS Research Grant, Johns Hopkins Center for AIDS Research Award P30AI094189, Gilead AIDS Research Grant (Y.-C.H.), Gilead HIV-1Research Scholar Grant, NIH BEAT-HIV1Delaney Collaboratory UM1Al126620 and NIH CHEETAH P50 Al150464-13.

\section{Availability of data and materials}

Not applicable.

\section{Ethics approval and consent to participate}

Not applicable.

\section{Consent for publication}

Not applicable.

\section{Competing interests}

The authors declare that they have no competing interests.

\section{Author details}

'Department of Microbial Pathogenesis, Yale University, New Haven, CT 06519, USA. '2Department of Medicine, Johns Hopkins University, Baltimore, MD 21205, USA

\section{Received: 17 October 2019 Accepted: 23 December 2019}

\section{Published online: 07 January 2020}

\section{References}

1. Chun TW, Carruth L, Finzi D, Shen X, DiGiuseppe JA, Taylor H, Hermankova M, Chadwick K, Margolick J, Quinn TC, et al. Quantification of latent tissue reservoirs and total body viral load in HIV-1 infection. Nature. 1997;387:183-8.

2. Finzi D, Hermankova M, Pierson T, Carruth LM, Buck C, Chaisson RE, Quinn TC, Chadwick K, Margolick J, Brookmeyer R, et al. Identification of a reservoir for HIV-1 in patients on highly active antiretroviral therapy. Science (New York, NY). 1997;278:1295-300.

3. Wong JK, Hezareh M, Gunthard HF, Havlir DV, Ignacio CC, Spina CA Richman DD. Recovery of replication-competent HIV despite prolonged suppression of plasma viremia. Science (New York, NY). 1997:278:1291-5.

4. Siliciano JD, Kajdas J, Finzi D, Quinn TC, Chadwick K, Margolick JB, Kovacs C, Gange SJ, Siliciano RF. Long-term follow-up studies confirm the stability of the latent reservoir for HIV-1 in resting CD4+ T cells. Nat Med. 2003;9:727-8.

5. Crooks AM, Bateson R, Cope AB, Dahl NP, Griggs MK, Kuruc JD, Gay CL, Eron JJ, Margolis DM, Bosch RJ, Archin NM. Precise quantitation of the latent HIV1 reservoir: implications for eradication strategies. J Infect Dis. 2015;212: $1361-5$

6. UNAIDS: Global Factsheets 2018. http://aidsinfounaidsorg/ 2019

7. Archin NM, Vaidya NK, Kuruc JD, Liberty AL, Wiegand A, Kearney MF, Cohen MS, Coffin JM, Bosch RJ, Gay CL, et al. Immediate antiviral therapy appears to restrict resting CD4+ cell HIV-1 infection without accelerating the decay of latent infection. Proc Natl Acad Sci U S A. 2012;109:9523-8.

8. Coffin JM, Wells DW, Zerbato JM, Kuruc JD, Guo S, Luke BT, Eron JJ, Bale M, Spindler J, Simonetti FR, et al. Clones of infected cells arise early in HIVinfected individuals. JCl Insight. 2019;4.

9. Abrahams M-R, Joseph SB, Garrett N, Tyers L, Moeser M, Archin N, Council OD, Matten D, Zhou S, Doolabh D, et al. The replication-competent HIV-1 latent reservoir is primarily established near the time of therapy initiation. Sci Transl Med. 2019;11:eaaw5589.

10. Bozzi G, Simonetti FR, Watters SA, Anderson EM, Gouzoulis M, Kearney MF, Rote P, Lange C, Shao W, Gorelick R, et al. No evidence of ongoing HIV replication or compartmentalization in tissues during combination antiretroviral therapy: Implications for HIV eradication. Sci Adv. 2019;5 eaav2045.

11. Maldarelli F, Wu X, Su L, Simonetti FR, Shao W, Hill S, Spindler J, Ferris AL, Mellors JW, Kearney MF, et al. HIV latency. Specific HIV integration sites are linked to clonal expansion and persistence of infected cells. Science (New York, NY). 2014;345:179-83.

12. Wagner TA, McLaughlin S, Garg K, Cheung CY, Larsen BB, Styrchak S, Huang HC, Edlefsen PT, Mullins JI, Frenkel LM. HIV latency. Proliferation of cells with HIV integrated into cancer genes contributes to persistent infection. Science (New York, NY). 2014;345:570-3.

13. Cohn LB, Silva IT, Oliveira TY, Rosales RA, Parrish EH, Learn GH, Hahn BH, Czartoski JL, McElrath MJ, Lehmann C, et al. HIV-1 integration landscape during latent and active infection. Cell. 2015;160:420-32.

14. Ho YC, Shan L, Hosmane NN, Wang J, Laskey SB, Rosenbloom DI, Lai J, Blankson JN, Siliciano JD, Siliciano RF. Replication-competent noninduced proviruses in the latent reservoir increase barrier to HIV-1 cure. Cell. 2013; 155:540-51

15. Bruner KM, Wang Z, Simonetti FR, Bender AM, Kwon KJ, Sengupta S, Fray EJ, Beg SA, Antar AAR, Jenike KM, et al. A quantitative approach for measuring the reservoir of latent HIV-1 proviruses. Nature. 2019:566:120-5.

16. Bruner KM, Murray AJ, Pollack RA, Soliman MG, Laskey SB, Capoferri AA, Lai J, Strain MC, Lada SM, Hoh R, et al. Defective proviruses rapidly accumulate during acute HIV-1 infection. Nat Med. 2016;22:1043-9.

17. Bui JK, Sobolewski MD, Keele BF, Spindler J, Musick A, Wiegand A, Luke BT, Shao W, Hughes SH, Coffin JM, et al. Proviruses with identical sequences comprise a large fraction of the replication-competent HIV reservoir. PLoS Pathog. 2017;13:e1006283.

18. Lorenzi JC, Cohen YZ, Cohn LB, Kreider EF, Barton JP, Learn GH, Oliveira T, Lavine $\mathrm{CL}$, Horwitz JA, Settler A, et al. Paired quantitative and qualitative assessment of the replication-competent HIV-1 reservoir and comparison with integrated proviral DNA. Proc Natl Acad Sci U S A. 2016;113:E7908-16.

19. Hosmane NN, Kwon KJ, Bruner KM, Capoferri AA, Beg S, Rosenbloom DI, Keele BF, Ho YC, Siliciano JD, Siliciano RF. Proliferation of latently infected CD4+ T cells carrying replication-competent HIV-1: potential role in latent reservoir dynamics. J Exp Med. 2017:214:959-72.

20. Kearney MF, Wiegand A, Shao W, McManus WR, Bale MJ, Luke B, Maldarelli F, Mellors JW, Coffin JM. Ongoing HIV replication during ART reconsidered. Open Forum Infect Dis. 2017;4:ofx173.

21. Rosenbloom DIS, Hill AL, Laskey SB, Siliciano RF. Re-evaluating evolution in the HIV reservoir. Nature. 2017;551:E6-e9.

22. Reeves DB, Duke ER, Wagner TA, Palmer SE, Spivak AM, Schiffer JT. A majority of HIV persistence during antiretroviral therapy is due to infected cell proliferation. Nat Commun. 2018:9:4811.

23. Chun TW, Justement JS, Murray D, Hallahan CW, Maenza J, Collier AC, Sheth PM, Kaul R, Ostrowski M, Moir S, et al. Rebound of plasma viremia following cessation of antiretroviral therapy despite profoundly low levels of HIV reservoir: implications for eradication. AIDS. 2010;24:2803-8.

24. Lu CL, Pai JA, Nogueira L, Mendoza P, Gruell H, Oliveira TY, Barton J, Lorenzi JCC, Cohen YZ, Cohn LB, et al. Relationship between intact HIV-1 proviruses in circulating CD4(+) T cells and rebound viruses emerging during treatment interruption. Proc Natl Acad Sci U S A. 2018;115:E11341-8.

25. Salantes DB, Zheng Y, Mampe F, Srivastava T, Beg S, Lai J, Li JZ, Tressler RL, Koup RA, Hoxie J, et al. HIV-1 latent reservoir size and diversity are stable following brief treatment interruption. J Clin Invest. 2018;128:3102-15.

26. Estes JD, Kityo C, Ssali F, Swainson L, Makamdop KN, Del Prete GQ, Deeks SG, Luciw PA, Chipman JG, Beilman GJ, et al. Defining total-body AIDS-virus burden with implications for curative strategies. Nat Med. 2017;23:1271-6.

27. Barton K, Hiener B, Winckelmann A, Rasmussen TA, Shao W, Byth K, Lanfear R, Solomon A, McMahon J, Harrington S, et al. Broad activation of latent HIV-1 in vivo. Nat Commun. 2016:7:12731.

28. Kearney MF, Wiegand A, Shao W, Coffin JM, Mellors JW, Lederman M, Gandhi RT, Keele BF, Li JZ. Origin of rebound plasma HIV includes cells with identical proviruses that are transcriptionally active before stopping of antiretroviral therapy. J Virol. 2016;90:1369-76.

29. De Scheerder MA, Vrancken B, Dellicour S, Schlub T, Lee E, Shao W, Rutsaert S, Verhofstede C, Kerre T, Malfait T, et al. HIV Rebound Is Predominantly Fueled by Genetically Identical Viral Expansions from Diverse Reservoirs. Cell Host Microbe. 2019;26:347-358.e347.

30. Hunt PW, Martin JN, Sinclair E, Bredt B, Hagos E, Lampiris H, Deeks SG. T cell activation is associated with lower CD4+ T cell gains in human 
immunodeficiency virus-infected patients with sustained viral suppression during antiretroviral therapy. J Infect Dis. 2003;187:1534-43.

31. Almeida CA, Price P, French MA. Immune activation in patients infected with HIV type 1 and maintaining suppression of viral replication by highly active antiretroviral therapy. AIDS Res Hum Retrovir. 2002;18:1351-5.

32. Wiegand A, Spindler J, Hong FF, Shao W, Cyktor JC, Cillo AR, Halvas EK, Coffin JM, Mellors JW, Kearney MF. Single-cell analysis of HIV-1 transcriptional activity reveals expression of proviruses in expanded clones during ART. Proc Natl Acad Sci U S A. 2017;114:E3659-68.

33. Hatano H, Jain V, Hunt PW, Lee TH, Sinclair E, Do TD, Hoh R, Martin JN, McCune JM, Hecht F, et al. Cell-based measures of viral persistence are associated with immune activation and programmed cell death protein 1 (PD-1)-expressing CD4+ T cells. J Infect Dis. 2013;208:50-6.

34. Pollack RA, Jones RB, Pertea M, Bruner KM, Martin AR, Thomas AS, Capoferri AA, Beg SA, Huang SH, Karandish S, et al. Defective HIV-1 Proviruses Are Expressed and Can Be Recognized by Cytotoxic T Lymphocytes, which Shape the Proviral Landscape. Cell host \& microbe. 2017;21:494-506.e494.

35. Eriksson S, Graf EH, Dahl V, Strain MC, Yukl SA, Lysenko ES, Bosch RJ, Lai J, Chioma $S$, Emad $F$, et al. Comparative analysis of measures of viral reservoirs in HIV-1 eradication studies. PLoS Pathog. 2013;9:e1003174.

36. Imamichi $\mathrm{H}$, Dewar RL, Adelsberger JW, Rehm CA, O'Doherty U, Paxinos EE, Fauci AS, Lane HC. Defective HIV-1 proviruses produce novel protein-coding RNA species in HIV-infected patients on combination antiretroviral therapy. Proc Natl Acad Sci U S A. 2016;113:8783-8.

37. Pinzone MR, VanBelzen DJ, Weissman S, Bertuccio MP, Cannon L, VenanziRullo E, Migueles S, Jones RB, Mota T, Joseph SB, et al. Longitudinal HIV sequencing reveals reservoir expression leading to decay which is obscured by clonal expansion. Nat Commun. 2019;10:728.

38. Simonetti FR, Sobolewski MD, Fyne E, Shao W, Spindler J, Hattori J, Anderson EM, Watters SA, Hill S, Wu X, et al. Clonally expanded CD4+ T cells can produce infectious HIV-1 in vivo. Proc Natl Acad Sci U S A. 2016; 113:1883-8.

39. Douek DC, Brenchley JM, Betts MR, Ambrozak DR, Hill BJ, Okamoto Y, Casazza JP, Kuruppu J, Kunstman K, Wolinsky S, et al. HIV preferentially infects HIV-specific CD4+ T cells. Nature. 2002;417:95-8.

40. Bosque A, Famiglietti M, Weyrich AS, Goulston C, Planelles V. Homeostatic proliferation fails to efficiently reactivate HIV-1 latently infected central memory CD4+ T cells. PLoS Pathog. 2011;7:e1002288.

41. Chomont N, El-Far M, Ancuta P, Trautmann L, Procopio FA, Yassine-Diab B, Boucher G, Boulassel MR, Ghattas G, Brenchley JM, et al. HIV reservoir size and persistence are driven by T cell survival and homeostatic proliferation. Nat Med. 2009;15:893-900.

42. Nettles RE, Kieffer TL, Kwon P, Monie D, Han Y, Parsons T, Cofrancesco J Jr, Gallant JE, Quinn TC, Jackson B, et al. Intermittent HIV-1 viremia (blips) and drug resistance in patients receiving HAART. Jama. 2005;293:817-29.

43. Wagner TA, McKernan JL, Tobin NH, Tapia KA, Mullins Jl, Frenkel LM. An increasing proportion of monotypic HIV-1 DNA sequences during antiretroviral treatment suggests proliferation of HIV-infected cells. J Virol. 2013;87:1770-8.

44. Kearney MF, Spindler J, Shao W, Yu S, Anderson EM, O'Shea A, Rehm C, Poethke C, Kovacs N, Mellors JW, et al. Lack of detectable HIV-1 molecular evolution during suppressive antiretroviral therapy. PLoS Pathog. 2014;10: e1004010.

45. Bailey JR, Sedaghat AR, Kieffer T, Brennan T, Lee PK, Wind-Rotolo M, Haggerty CM, Kamireddi AR, Liu Y, Lee J, et al. Residual human immunodeficiency virus type 1 viremia in some patients on antiretrovira therapy is dominated by a small number of invariant clones rarely found in circulating CD4+ T cells. J Virol. 2006;80:6441-57.

46. Wang Z, Gurule EE, Brennan TP, Gerold JM, Kwon KJ, Hosmane NN, Kumar MR, Beg SA, Capoferri AA, Ray SC, et al. Expanded cellular clones carrying replication-competent HIV-1 persist, wax, and wane. Proc Natl Acad Sci U S A. 2018;115(11):E2575-84

47. Halvas EKJ K, Brandt LD, Botha JC, Sobolewski M, Jacobs JL, Keele BF, Kearney MF, Coffin JM, Rausch JW, Guo S, et al. Nonsuppressible viremia on ART from large cell clones carrying intact proviruses. Boston: Conferences on Retroviruses and Opportunistic Infections; 2019.

48. Rosenberg ES, Billingsley JM, Caliendo AM, Boswell SL, Sax PE, Kalams SA, Walker BD. Vigorous HIV-1-specific CD4+ T cell responses associated with control of viremia. Science. 1997;278:1447-50.

49. Lee GQ, Orlova-Fink N, Einkauf K, Chowdhury FZ, Sun X, Harrington S, Kuo $\mathrm{HH}$, Hua S, Chen HR, Ouyang Z, et al. Clonal expansion of genome-intact
HIV-1 in functionally polarized Th1 CD4+ T cells. J Clin Invest. 2017;127: 2689-96.

50. Hiener B, Horsburgh BA, Eden JS, Barton K, Schlub TE, Lee E, von Stockenstrom S, Odevall L, Milush JM, Liegler T, et al. Identification of genetically intact HIV-1 proviruses in specific CD4(+) T cells from effectively treated participants. Cell Rep. 2017;21:813-22.

51. Kaufmann DE, Bailey PM, Sidney J, Wagner B, Norris PJ, Johnston MN, Cosimi LA, Addo MM, Lichterfeld M, Altfeld M, et al. Comprehensive analysis of human immunodeficiency virus type 1-specific CD4 responses reveals marked immunodominance of gag and nef and the presence of broadly recognized peptides. J Virol. 2004;78:4463-77.

52. Pitcher CJ, Quittner C, Peterson DM, Connors M, Koup RA, Maino VC, Picker LJ. HIV-1-specific CD4+ T cells are detectable in most individuals with active HIV-1 infection, but decline with prolonged viral suppression. Nat Med. 1999:5:518-25.

53. Betts MR, Ambrozak DR, Douek DC, Bonhoeffer S, Brenchley JM, Casazza JP, Koup RA, Picker LJ. Analysis of total human immunodeficiency virus (HIV)specific CD4(+) and CD8(+) T-cell responses: relationship to viral load in untreated HIV infection. J Virol. 2001;75:11983-91.

54. Meyaard L, Otto SA, Jonker RR, Mijnster MJ, Keet RP, Miedema F. Programmed death of T cells in HIV-1 infection. Science. 1992;257:217-9.

55. Sousa AE, Carneiro J, Meier-Schellersheim M, Grossman Z, Victorino RM. CD4 T cell depletion is linked directly to immune activation in the pathogenesis of HIV-1 and HIV-2 but only indirectly to the viral load. J Immunol. 2002;169:3400-6.

56. Porichis F, Hart MG, Massa A, Everett HL, Morou A, Richard J, Brassard N, Veillette M, Hassan M, Ly NL, et al. Immune checkpoint blockade restores HIV-specific CD4 T cell help for NK cells. J Immunol. 2018;201:971-81.

57. Porichis F, Kwon DS, Zupkosky J, Tighe DP, McMullen A, Brockman MA, Pavlik DF, Rodriguez-Garcia M, Pereyra F, Freeman GJ, et al. Responsiveness of HIV-specific CD4 T cells to PD-1 blockade. Blood. 2011;118:965-74.

58. Day CL, Kaufmann DE, Kiepiela P, Brown JA, Moodley ES, Reddy S, Mackey EW, Miller JD, Leslie AJ, DePierres C, et al. PD-1 expression on HIV-specific T cells is associated with T-cell exhaustion and disease progression. Nature. 2006:443:350-4.

59. Schacker TW, Nguyen PL, Beilman GJ, Wolinsky S, Larson M, Reilly C, Haase AT. Collagen deposition in HIV-1 infected lymphatic tissues and T cell homeostasis. J Clin Invest. 2002;110:1133-9.

60. Brenchley JM, Schacker TW, Ruff LE, Price DA, Taylor JH, Beilman GJ, Nguyen PL, Khoruts A, Larson M, Haase AT, Douek DC. CD4+ T cell depletion during all stages of HIV disease occurs predominantly in the gastrointestinal tract. J Exp Med. 2004;200:749-59.

61. Estes J, Baker JV, Brenchley JM, Khoruts A, Barthold JL, Bantle A, Reilly CS, Beilman GJ, George ME, Douek DC, et al. Collagen deposition limits immune reconstitution in the gut. J Infect Dis. 2008;198:456-64.

62. Laurent-Crawford AG, Krust B, Muller S, Riviere Y, Rey-Cuille MA, Bechet JM, Montagnier L, Hovanessian AG. The cytopathic effect of HIV is associated with apoptosis. Virology. 1991;185:829-39.

63. Ndhlovu ZM, Kazer SW, Nkosi T, Ogunshola F, Muema DM, Anmole G, Swann SA, Moodley A, Dong K, Reddy T, et al. Augmentation of HIV-specific $T$ cell function by immediate treatment of hyperacute HIV-1 infection. Sci Transl Med. 2019;11(493):eaau0528. https://doi.org/10.1126/scitranslmed. aau0528.

64. Geldmacher C, Schuetz A, Ngwenyama N, Casazza JP, Sanga E, Saathoff E, Boehme C, Geis S, Maboko L, Singh M, et al. Early depletion of mycobacterium tuberculosis-specific T helper 1 cell responses after HIV-1 infection. J Infect Dis. 2008;198:1590-8.

65. Geldmacher C, Ngwenyama N, Schuetz A, Petrovas C, Reither K, Heeregrave EJ, Casazza JP, Ambrozak DR, Louder M, Ampofo W, et al. Preferential infection and depletion of mycobacterium tuberculosis-specific CD4 T cells after HIV-1 infection. J Exp Med. 2010;207:2869-81.

66. Riou C, Tanko RF, Soares AP, Masson L, Werner L, Garrett NJ, Samsunder N, Karim QA, Karim SSA, Burgers WA. Restoration of CD4+ responses to Copathogens in HIV-infected individuals on antiretroviral therapy is dependent on T cell memory phenotype. J Immunol. 2015. 195:2273-81.

67. Liu F, Fan X, Auclair S, Ferguson M, Sun J, Soong L, Hou W, Redfield RR, Birx $D L$, Ratto-Kim S, et al. Sequential dysfunction and progressive depletion of Candida albicans-specific CD4 T cell response in HIV-1 infection. PLoS Pathog. 2016;12:e1005663.

68. Papagno L, Appay $\vee$, Sutton J, Rostron T, Gillespie GM, Ogg GS, King A, Makadzanhge AT, Waters A, Balotta C, et al. Comparison between HIV- and 
CMV-specific T cell responses in long-term HIV infected donors. Clin Exp Immunol. 2002;130:509-17.

69. Hu H, Nau M, Ehrenberg P, Chenine AL, Macedo C, Zhou Y, Daye ZJ, Wei Z, Vahey M, Michael NL, et al. Distinct gene-expression profiles associated with the susceptibility of pathogen-specific CD4 T cells to HIV-1 infection. Blood. 2013;121:1136-44.

70. Gomez-Mora E, Garcia E, Urrea V, Massanella M, Puig J, Negredo E, Clotet B, Blanco J, Cabrera C. Preserved immune functionality and high CMV-specific T-cell responses in HIV-infected individuals with poor CD4(+) T-cell immune recovery. Sci Rep. 2017;7:11711.

71. Kassu A, Marcus RA, D'Souza MB, Kelly-McKnight EA, Golden-Mason L, Akkina R, Fontenot AP, Wilson CC, Palmer BE. Regulation of virus-specific CD4+ T cell function by multiple costimulatory receptors during chronic HIV infection. J Immunol. 2010;185:3007-18.

72. Casazza JP, Brenchley JM, Hill BJ, Ayana R, Ambrozak D, Roederer M, Douek DC, Betts MR, Koup RA. Autocrine production of beta-chemokines protects CMV-specific CD4 T cells from HIV infection. PLoS Pathog. 2009;5:e1000646.

73. Geldmacher C, Koup RA. Pathogen-specific T cell depletion and reactivation of opportunistic pathogens in HIV infection. Trends Immunol. 2012;33:207-14.

74. Brenchley JM, Hill BJ, Ambrozak DR, Price DA, Guenaga FJ, Casazza JP, Kuruppu J, Yazdani J, Migueles SA, Connors M, et al. T-cell subsets that harbor human immunodeficiency virus (HIV) in vivo: implications for HIV pathogenesis. J Virol. 2004;78:1160-8.

75. Arens R, Wang P, Sidney J, Loewendorf A, Sette A, Schoenberger SP, Peters $B$, Benedict CA. Cutting edge: murine cytomegalovirus induces a polyfunctional CD4 T cell response. J Immunol. 2008;180:6472-6.

76. Kondrack RM, Harbertson J, Tan JT, McBreen ME, Surh CD, Bradley LM. Interleukin 7 regulates the survival and generation of memory CD4 cells. J Exp Med. 2003;198:1797-806.

77. Lenz DC, Kurz SK, Lemmens E, Schoenberger SP, Sprent J, Oldstone MB, Homann D. IL-7 regulates basal homeostatic proliferation of antiviral CD4+T cell memory. Proc Natl Acad Sci U S A. 2004;101:9357-62.

78. Seddon B, Tomlinson P, Zamoyska R. Interleukin 7 and T cell receptor signals regulate homeostasis of CD4 memory cells. Nat Immunol. 2003;4: 680-6.

79. Rethi B, Fluur C, Atlas A, Krzyzowska M, Mowafi F, Grutzmeier S, De Milito A, Bellocco R, Falk KI, Rajnavolgyi E, Chiodi F. Loss of IL-7Ralpha is associated with CD4 T-cell depletion, high interleukin-7 levels and CD28 downregulation in HIV infected patients. Aids. 2005;19:2077-86.

80. Okoye A, Meier-Schellersheim M, Brenchley JM, Hagen SI, Walker JM, Rohankhedkar M, Lum R, Edgar JB, Planer SL, Legasse A, et al. Progressive CD4+ central memory $T$ cell decline results in CD4+ effector memory insufficiency and overt disease in chronic SIV infection. J Exp Med. 2007;204:2171-85.

81. D'Souza M, Fontenot AP, Mack DG, Lozupone C, Dillon S, Meditz A, Wilson CC, Connick E, Palmer BE. Programmed death 1 expression on HIV-specific CD4+ T cells is driven by viral replication and associated with $T$ cell dysfunction. J Immunol. 2007;179:1979-87.

82. Kaufmann DE, Kavanagh DG, Pereyra F, Zaunders JJ, Mackey EW, Miura T, Palmer S, Brockman M, Rathod A, Piechocka-Trocha A, et al. Upregulation of CTLA-4 by HIV-specific CD4+ T cells correlates with disease progression and defines a reversible immune dysfunction. Nat Immunol. 2007:8:1246-54.

83. Zeng M, Southern PJ, Reilly CS, Beilman GJ, Chipman JG, Schacker TW, Haase AT. Lymphoid tissue damage in HIV-1 infection depletes naive T cells and limits T cell reconstitution after antiretroviral therapy. PLoS Pathog. 2012;8:e1002437.

84. Napolitano LA, Grant RM, Deeks SG, Schmidt D, De Rosa SC, Herzenberg LA, Herndier BG, Andersson J, McCune JM. Increased production of IL-7 accompanies HIV-1-mediated T-cell depletion: implications for T-cell homeostasis. Nat Med. 2001:7:73-9.

85. Vandergeeten C, Fromentin R, DaFonseca S, Lawani MB, Sereti I, Lederman MM, Ramgopal M, Routy JP, Sekaly RP, Chomont N. Interleukin-7 promotes HIV persistence during antiretroviral therapy. Blood. 2013;121:4321-9.

86. Katlama C, Lambert-Niclot S, Assoumou L, Papagno L, Lecardonnel F, Zoorob R, Tambussi G, Clotet B, Youle M, Achenbach CJ, et al. Treatment intensification followed by interleukin-7 reactivates HIV without reducing total HIV DNA: a randomized trial. Aids. 2016;30:221-30.

87. Rous P. A sarcoma of the fowl transmissible by an agent separable from the tumor cells. J Exp Med. 1911;13:397-411.

88. Cavazzana-Calvo M, Hacein-Bey S, de Saint BG, Gross F, Yvon E, Nusbaum P, Selz F, Hue C, Certain S, Casanova JL, et al. Gene therapy of human severe combined immunodeficiency (SCID)-X1 disease. Science. 2000;288:669-72.
89. Hacein-Bey-Abina S, Garrigue A, Wang GP, Soulier J, Lim A, Morillon E, Clappier E, Caccavelli L, Delabesse E, Beldjord K, et al. Insertional oncogenesis in 4 patients after retrovirus-mediated gene therapy of SCIDX1. J Clin Invest. 2008:118:3132-42.

90. Wu X, Li Y, Crise B, Burgess SM. Transcription start regions in the human genome are favored targets for MLV integration. Science. 2003;300:1749-51.

91. Cavazzana-Calvo M, Payen E, Negre O, Wang G, Hehir K, Fusil F, Down J, Denaro M, Brady T, Westerman K, et al. Transfusion independence and HMGA2 activation after gene therapy of human beta-thalassaemia. Nature. 2010;467:318-22.

92. Fraietta JA, Nobles CL, Sammons MA, Lundh S, Carty SA, Reich TJ, Cogdill AP, Morrissette JJD, DeNizio JE, Reddy S, et al. Disruption of TET2 promotes the therapeutic efficacy of CD19-targeted T cells. Nature. 2018;558:307-12.

93. Poiesz BJ, Ruscetti FW, Gazdar AF, Bunn PA, Minna JD, Gallo RC. Detection and isolation of type $C$ retrovirus particles from fresh and cultured lymphocytes of a patient with cutaneous T-cell lymphoma. Proc Natl Acad Sci U S A. 1980;77:7415-9.

94. Yoshida M, Miyoshi I, Hinuma Y. Isolation and characterization of retrovirus from cell lines of human adult T-cell leukemia and its implication in the disease. Proc Natl Acad Sci U S A. 1982;79:2031-5.

95. Bangham CRM. Human T cell leukemia virus type 1: persistence and pathogenesis. Annu Rev Immunol. 2018;36:43-71.

96. Satou Y, Miyazato P, Ishihara K, Yaguchi H, Melamed A, Miura M, Fukuda A, Nosaka K, Watanabe T, Rowan AG, et al. The retrovirus HTLV-1 inserts an ectopic CTCF-binding site into the human genome. Proc Natl Acad Sci U S A. 2016;113:3054-9.

97. Cook LB, Melamed A, Niederer H, Valganon M, Laydon D, Foroni L, Taylor GP, Matsuoka M, Bangham CR. The role of HTLV-1 clonality, proviral structure, and genomic integration site in adult T-cell leukemia/lymphoma. Blood. 2014;123:3925-31.

98. Gillet NA, Malani N, Melamed A, Gormley N, Carter R, Bentley D, Berry C, Bushman FD, Taylor GP, Bangham CR. The host genomic environment of the provirus determines the abundance of HTLV-1-infected T-cell clones. Blood. 2011;117:3113-22.

99. Schroder AR, Shinn P, Chen H, Berry C, Ecker JR, Bushman F. HIV-1 integration in the human genome favors active genes and local hotspots. Cell. 2002;1 10:521-9.

100. Han Y, Lassen K, Monie D, Sedaghat AR, Shimoji S, Liu X, Pierson TC, Margolick $J B$, Siliciano RF, Siliciano JD. Resting CD4+ T cells from human immunodeficiency virus type 1 (HIV-1)-infected individuals carry integrated HIV-1 genomes within actively transcribed host genes. J Virol. 2004;78:6122-33.

101. Shan L, Yang HC, Rabi SA, Bravo HC, Shroff NS, Irizarry RA, Zhang H, Margolick JB, Siliciano JD, Siliciano RF. Influence of host gene transcription level and orientation on HIV-1 latency in a primary-cell model. J Virol. 2011; 85:5384-93.

102. Sowd GA, Serrao E, Wang H, Wang W, Fadel HJ, Poeschla EM, Engelman AN. A critical role for alternative polyadenylation factor CPSF6 in targeting HIV-1 integration to transcriptionally active chromatin. Proc Natl Acad Sci U S A. 2016;113:E1054-63.

103. Ciuffi A, Llano M, Poeschla E, Hoffmann C, Leipzig J, Shinn P, Ecker JR, Bushman F. A role for LEDGF/p75 in targeting HIV DNA integration. Nat Med. 2005;11:1287-9.

104. Berry CC, Gillet NA, Melamed A, Gormley N, Bangham CR, Bushman FD. Estimating abundances of retroviral insertion sites from DNA fragment length data. Bioinformatics (Oxford, England). 2012;28:755-62.

105. Ikeda T, Shibata J, Yoshimura K, Koito A, Matsushita S. Recurrent HIV-1 integration at the $\mathrm{BACH} 2$ locus in resting $\mathrm{CD} 4+\mathrm{T}$ cell populations during effective highly active antiretroviral therapy. J Infect Dis. 2007;195:716-25.

106. Cesana D, Santoni de Sio FR, Rudilosso L, Gallina P, Calabria A, Beretta S, Merelli I, Bruzzesi E, Passerini L, Nozza S, et al. HIV-1-mediated insertional activation of STAT5B and BACH2 trigger viral reservoir in T regulatory cells. Nat Commun. 2017;8:498.

107. Ferris AL, Wells DW, Guo S, Del Prete GQ, Swanstrom AE, Coffin JM, Wu X, Lifson JD, Hughes SH. Clonal expansion of SIV-infected cells in macaques on antiretroviral therapy is similar to that of HIV-infected cells in humans. PLoS Pathog. 2019;15:e1007869.

108. Snyder CM, Cho KS, Bonnett EL, van Dommelen S, Shellam GR, Hill AB. Memory inflation during chronic viral infection is maintained by continuous production of short-lived, functional T cells. Immunity. 2008;29:650-9.

109. Einkauf KB, Lee GQ, Gao C, Sharaf R, Sun X, Hua S, Chen SM, Jiang C, Lian X, Chowdhury FZ, et al. Intact HIV-1 proviruses accumulate at distinct 
chromosomal positions during prolonged antiretroviral therapy. J Clin Invest. 2019;129(3):988-98. https://doi.org/10.1172/JCl124291.

110. Patro SC, Brandt LD, Bale MJ, Halvas EK, Joseph KW, Shao W, Wu X, Guo S, Murrell B, Wiegand A, et al. Combined HIV-1 sequence and integration site analysis informs viral dynamics and allows reconstruction of replicating viral ancestors. Proc Natl Acad Sci U S A. 2019;116(51):25891-9. https://doi.org/10. 1073/pnas.1910334116

111. Ho YC. Identification of integration sites of inducible HIV-1 using HIV-1 RNA SortSeq. In: Conferences on Retroviruses and Opportunistic Infections; Boston, Massachusetts; 2019.

112. Han Y, Lin YB, An W, Xu J, Yang HC, O'Connell K, Dordai D, Boeke JD, Siliciano JD, Siliciano RF. Orientation-dependent regulation of integrated HIV-1 expression by host gene transcriptional readthrough. Cell Host Microbe. 2008;4:134-46.

113. Lenasi T, Contreras X, Peterlin BM. Transcriptional interference antagonizes proviral gene expression to promote HIV latency. Cell Host Microbe. 2008:4:123-33.

114. Sherrill-Mix S, Ocwieja KE, Bushman FD. Gene activity in primary T cells infected with HIV89.6: intron retention and induction of genomic repeats. Retrovirology. 2015;12:79-015-0205-0201.

115. Lucic B, Chen HC, Kuzman M, Zorita E, Wegner J, Minneker V, Wang W, Fronza $R$, Laufs S, Schmidt M, et al. Spatially clustered loci with multiple enhancers are frequent targets of HIV-1 integration. Nat Commun. 2019;10:4059.

116. Marini B, Kertesz-Farkas A, Ali H, Lucic B, Lisek K, Manganaro L, Pongor S, Luzzati R, Recchia A, Mavilio F, et al. Nuclear architecture dictates HIV-1 integration site selection. Nature. 2015;521:227-31.

117. Reeves DB, Duke ER, Hughes SM, Prlic M, Hladik F, Schiffer JT. Antiproliferative therapy for HIV cure: a compound interest approach. Sci Rep. 2017;7:4011

\section{Publisher's Note}

Springer Nature remains neutral with regard to jurisdictional claims in published maps and institutional affiliations.

Ready to submit your research? Choose BMC and benefit from:

- fast, convenient online submission

- thorough peer review by experienced researchers in your field

- rapid publication on acceptance

- support for research data, including large and complex data types

- gold Open Access which fosters wider collaboration and increased citations

- maximum visibility for your research: over $100 \mathrm{M}$ website views per year

At $\mathrm{BMC}$, research is always in progress.

Learn more biomedcentral.com/submissions 